\title{
The Improvement of Short Story Reading and Writing Skill through Project-Based Learning
}

\author{
Tri Susana* \\ Universitas Negeri Yogyakarta \\ Yogyakarta, Indonesia \\ susan3susan@yahoo.com
}

\author{
Anwar Efendi \\ Universitas Negeri Yogyakarta \\ Yogyakarta, Indonesia \\ anwar@uny.ac.id
}

\begin{abstract}
This research is aimed at improving short story reading and writing skills through project-based learning. The research conducted was classroom action research which consisted of four stages : (a) planning, (b) action, (c) observation, (d) reflection. The subject of the research was the students of class IXF Junior High School Negeri 1 Ngluwar. The research was conducted in 2 cycles, in which each cycle consisted of two meetings. The data collection employed an observation sheet, a scoring guidance sheet, an achievement test, activity documentation, and a field note. The data analysis was conducted quantitatively and quantitatively. It is proven that learning based project is able to improve short story reading and writing skilll.
\end{abstract}

Keywords - project-based learning, reading, writing, short story

\section{INTRODUCTION}

Development of technology and information has impact on student learning style that is more practical. Related to Indonesian language learning, students should use their Indonesian language skills to improve communication skills to be more effectively and rationally. However, not all students have good understanding of the concept of reading and writing in good and proper Indonesian language, especially the concept of short story reading material.

Reading and writing is strongly related to each other since those activities are conducted by applying studentscentered learning. On the other words, students should be active in the learning process in order to get more comprehension of the material. In addition, reading and writing is the means to get richer understanding of Indonesian language literacy.

Teachers apply a curriculum which has been prepared and made in the beginning of school year. This application may hamper the variety of learning materials in case the materials do not match the curriculum. Even though a curriculum is used to focus on certain educational purpose, the teachers need to find more creative ways to combine the guidance in the curriculum with the application of learning process based on the students need and capability.

In relation with reading text or material, Mahsun (2013:15) defined text as the integration of writing, situation, and context. Students' needs and text genre should complete each other in order to get the best formulation of learning process. Hence, the teachers must consider the background of the reading materials and adjust the literacy with the students' environment, condition, and capability.
In addition, Tompkins and Hoskisson (1995:86) stated that reading is a process of translating messages delivered by the writer. In this activity, there is a transcational process of giving-taking messages. Readers can negotiate the meaning or interpret the message. Smith (1994) declared that reading is not only digging information from reading material but also connecting information from the reading with the knowledge possesed by the readers in order to shape certain learning style. By this, reading is a means to deepen knowledge and readers can apply it in the daily lives.

Saka (104) stated that short story is short and contains easily understood language adjusting the reading genre so that reading it can elevate readers' curiosity to read further and to appreciate literature more. The effect, hence, is that reading short story can encourage students to do positive learning activity.

Due to the practical purpose, short story usually has one plot only and few roles. Ambras (1970:158) stated that the simple structures of a short story can stimulate students' thinking; to have more interesting imagination on what will happen next since the short story content sometimes matches what happens in the daily lives of the roles. Students can also make opinion on how certain characters in the short story should behave since students want to create the short story content based on their expectation.

In relation to writing, Hedge (2005:10) state that writing aims to guide students to make overall communication tools by connecting information, ideas, or opinions for certain readers groups. Hayes (2002:19) added that writing is a social activity since it refers to culture of that society. Specifically, writer can establish writing style or diction based on the cultural background affecting the readers that is related to writer identity. It can be said that writing is also a social phenomenon; the writer writes his experiences which are reflected in the writing both in the diction and writing style. The writing result can also function as an information trade tool of a certain culture and promotion as well.

Discussing project-based learning, Buck Institute for Education (1999) in Trianto (2014:41) explained that it is a model to shift the learning model from short, isolated, teacher-centered lessons to a long-term, interdisciplinary, student-centered, and real world-integrated learning model.

Project-based learning is chosen as the independent variable to improve the skills of reading and writing short story on the research subjects who were the students of grade IX at Junior High School Negeri 1 Ngluwar. The research significance is useful to look for justificaton of project-based learning project model as an effective learning model to 
promote students activeness in reading and writing short story.

The solution offered is in the form of stages in conducting project-based learning. Students choose a topic for the short story related to their real world so that it is easily understood. Dicussion is done between the teachers and the students about the project planning. In the discussion, the schedule of project execution, project progress monitoring, result and evalution testing are arranged. All the discussion result is implemented in the agreed framework between the teachers and the students.

Figure 1. Stages of Project-based Learning

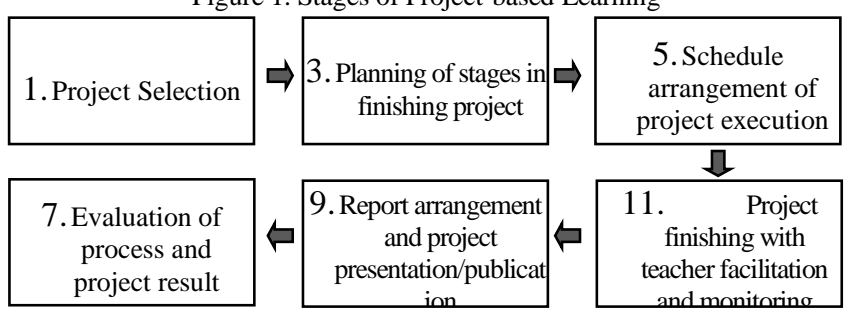

In the previous research, Endang (2017) wrote a thesis entitled "Application of Project Based-learning Model in Transforming Short Story into Movie Orienting to Character Education of students grade XI Senior High School Negeri 1 Cipatat West Bandung Regency." This research was quasi experiment research with a quantitative approach. Based on the hypothesis testing, project based-learning model had an impact to the skill of transforming short story into movie.

In addition, Rauf (2015) wrote a thesis entitled "Application of Project Based-learning Model in Improving Writing Short Story Skill of Students Grade XI MIA 4 Senior High School Negeri 2 Takalar." This research was classroom action research conducted in two cycles. From the research, it was concluded that project based-learning could improve the skill of writing short story of the grade XI students of MIA Senior High School Negeri 2 Takalar.

Project-based learning is a relevant way to formulate the mutual function of reading and writing in which they complete each other (Hunchinson \& Waters, 1987). The researcher, hence, should focus on the progress of student activities during the learning focus in order to find the best formulation of learning process.

From various problem formulation framework, mindset framework, and relevant previous research, then hypothesis is constructed that Project-based learning can improve the skills of writing and reading short story of the students. The visual information of the researcher about the students capability in reading and writing short story is significant to determine the best forms of the project.

\section{METHOD}

This research is classroom action research covering planning, action, observation, and reflection (Kemmis \& Mc. Taggart, 1994:14). The research was done in 2 cycles. The first cycle was to find out students' understanding of short story building elements that the result of which was used to arrange a project-based research action for the second cycle. The conclusion of research result was taken from test instruments (students score) and non test instruments (questionnaire and observation).

The research was conducted from October 2018 to February 2019 at Junior High School Negeri 1 Ngluwar, Magelang Regency. The research subject was the students of class IX F of Junior High School Negeri 1 Ngluwar, Magelang Regency, Central Java Province in the in odd semester of school year 2018/2019. The number of the students were 28 which consisted of 12 male students and 16 female students.

The sampling variables and research data were analyzed using triangulation which were using data validity checking by means of comparing and crosschecking the degree of trustworthiness of any information received through different times and tools using a qualitative method. The data analysis technique applied Presentation Scoring Indicator (NP), Accumulative Score (NK), and the number of respondents (R).

$$
\mathrm{NP}=\underset{\mathrm{R}}{\mathrm{NK}} \mathrm{---} \text { x 100\% }
$$

\section{RESULT AND DISCUSSION}

Before learning using project based-learning model, the skills of students in reading and writing short story are still very low. It is proven in the assessment result received that there were still many students who did not complete the task. The scoring result in the reading skill was $21.4 \%$ i.e. only 6 students completed the task, whereas the scoring result of writing skill was $17.9 \%$ which means only 5 out of 28 students completed the task. The teachers apply the learning process based on the current curriculum and previous method which does not focus on students.

Beside a result assessment, a process assessment is also conducted during the ongoing learning. In this phase, the students were not active yet in following the lesson, they were not cooperative in group discussion, and did not display confident behavior in presenting discussion result. A process assessment is very significant to prepare the best learning material or project for the students. From the process assessment, the teacher found out what the students needed and wanted in their learning process.

The scoring result in the prior result was used to conduct action reflection focusing on student activeness, cooperation in discussion, and the growth of self confidence in presenting discussion result. The teachers chose project-based learning to improve the process and learning outcome of reading and writing short story.

In the first cycle, there was improvement of result of scoring and learning process started to improve. During the learning of reading in cycle $\mathrm{I}$, the researcher along with a collaborator conducted thorough observation by using a research instrument which had been prepared before. The observation was equipped with documentation in the forms of pictures and working result of the students during the learning and assessing process. The process observation was aimed at finding out the activity done by the students during learning process and the teacher activities in using project- 
based learning. Product observation was in the forms of students achievement outcome in the learning material of identifying understanding, characteristics, and short story building elements.

From the observation result in cycle 1, it was found that most students had experienced improvement in the activeness in following lesson, been cooperating in discussion, and shown confidence in presentation. Meanwhile, the teacher activities in guiding students in learning had applied project-based learning. In addition, from the scoring result, it was found out that there was improvement in learning completeness from $21.4 \%$ to $67.8 \%$.

During the learning of writing short story in cycle I, the researcher along with the collaborator conducted the same actions as what was done in reading class (thorough observation by using research instrument). The observation was also equipped with documentation of pictures and working result of the students during learning and assessing process. The process observation aimed to find out the students activity during learning process, teachers activity in using project based-learning. The product observations were in form of achievement result of the student in the materials of interpreting the structure of short story reading material and interpreting the elements of literacy in the short story reading material.

Based on the observation result form the cycle 1, the information obtained was that most students experienced improvement in term of activeness in lessons following, cooperating in the discussion, and showing confidence in presentaton. Meanwhile, teachers activity in guiding students in learning had applied project based-learning. In addition, from the assessing result, it was found out that there was improvement of learning completeness at $46.4 \%$.

In the reflection stage, the researcher along with collaborator discussed and analyzed the process and result of action performed in cycle I. Reflection activity is based on the achievement of research success indicators.

In the process of learning, there were three students who seemed to experience improvement in learning reading short story reading material. The improvement was in the form of the activeness of students, cooperation in discussion, and the growth of self confidence in presenting the discussion result. However, there was a weakness created which was the lack of reference in material of reading short story reading material. That hindered students in finding out the concept of short story building elements. Besides, there were still some students who were not active in discussion activity and shy of coming forward to present the result of the group discussion.

The result of completeness achievement in cycle I was $67.8 \%$ i.e. 19 out of 28 students completed the task, whereas 8 students did not complete it. This shows that the achievement of completenss is still below the standard of action success. The standard of action sucess is that $75 \%$ of the students achieve learning completeness.

It can be concluded that cycle I has not been successful yet. That is why, it is necessary to offer a remedy in conducting learning using project-based learning to achieve a maximum result. In the next cycle, all students were expected to be successful in achieving completeness standard.

Based on the observation in cycle II, some information was received that most students had experienced improvement in terms of activeness in the next classes, cooperating in discussion, and showing self confidence in the presentation. Meanwhile, the teachers guided students in the learning process using project-based learning with a remedy. Meanwhile, from the assessment result, it was found out that improvement on learning completeness occured from $67.8 \%$ to $96.4 \%$. There was only 1 student who did not complete the task. This was caused by the student's lack of competence. Overall, that student had already got repeating remedial activities but had not yet succeeded in meeting the completeness standard. Nonetheless, the student's lack of understanding couldnot be improved since the student has disadvantaged background of education and family.

After doing cycle II, the researcher along with collaborator evaluated all the plans, observations, and actions that had been carried out. Based on the evaluation, the use of project-based learning is able to show the improvement of the skills in reading short story material seen both from the process and the achievement result.

The improvement of the process occured in the improvement of learning quality from the beginning establishment of cycle I to the end of cycle II. The students activeness improved, the cooperation in discussion also appeared in all groups, and the self confidence grew well.

The improvement in reading short story can be seen from the learning completeness in cycle I and cycle II. The minimum completeness standard for Indonesian language subject of Junior High School Negeri 1 Ngluwar is 75. In the cycle I, the completeness reached $64.3 \%$ then in cycle II it improved to $96.4 \%$. That is why, the researcher considers that the establishment of learning using project-based learning has succedded to achieve learning completeness optimally.

Following is the table presenting the skill improvement of reading short story material in cycle I and cycle II

Table 1. Improvement of Skill Result of Reading Short Story

\begin{tabular}{ccccc} 
No. & Details & Cycle 1 & Cycle II & Improvement \\
\hline 1. & Score average & 75 & 85 & $10 \%$ \\
2. & Number of & 19 & 27 & $28.6 \%$ \\
& participants & & & \\
3. & Percentage & $67.8 \%$ & $96.4 \%$ & $28.6 \%$ \\
\hline
\end{tabular}

From the above table, it can be concluded that there is significant improvement in cycle II. The average reading skill of short story material has fulfilled the achievement indicator which is beyond the limit of classical learning completeness or more than minimum completeness standard. It is proven that project-based learning model can improve the skill of reading short story material of the students of IXF at Junior High School Negeri 1 Ngluwar. 
Figure 2. Graph of Improvement of Reading Skill Result

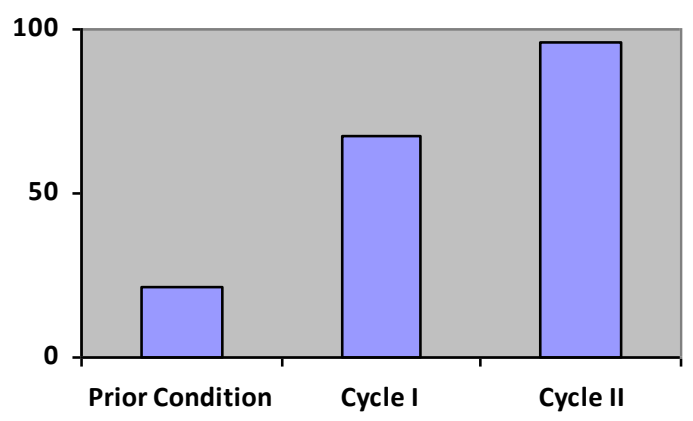

From the above graph, it can be concluded that there is significant improvement in cycle II. The average students score is beyond the minimum completeness standard. Herewith, it is proven that project-based learning is able to improve reading skill.

In the learning process, there are three things appear to have improvement in the learning of reading short story, which are student activeness, cooperation in discussion, and the growth of confidence in delivering presentation of discussion result. However, there is one weakness created which is the lack of students reference of the material of reading short story. It hinders the students in finding out the concept of short story building elements. Besides, there are still some students who are not active yet in the discussion activity and are shy in presenting the result of group discussion.

Students are more confident of searching for better understanding of a short story by reading. They start to connect all the elements of learning with their improving learning capability. The lack of student reference of the other relevant short story materials or Indonesian literacy is gradually overcome by their continous learning and communication in the group.

Of the skill of writing short story, the result of scoring in cycle I of writing short story revealed that only $46.4 \%$ completed the task. Then action reflection was done focusing on students activeness, cooperation in discussion, and the growth of self confidence in presenting the result of discussion and then it is made into project-based learning to be applied in the cycle II. The result was $92.90 \%$ completed the task. Even though there were two students who did not complete it, the cycle cannot be continued since the indicator of competency achievement had been reached.

Figure 3. The improvement of skill result of wring short story cycle II

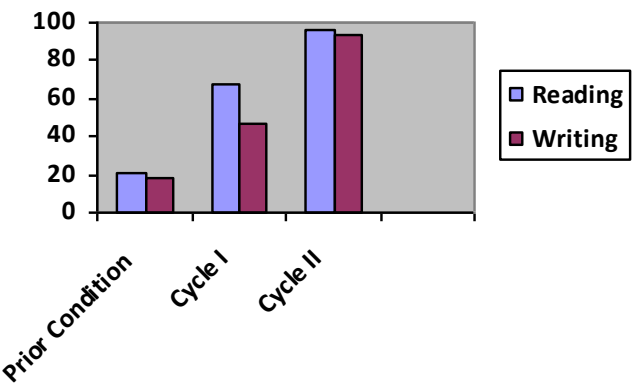

Following is the end result of skill improvement of reading and writing short story material with project-based learning. Overall, the teacher functioned as a facilitator and an advisor for the students to get more reference. This learning process focused on students-centered learning process. Consequently, the teachers must be fully prepared i.e. demonstrating extensive knowledge and references in order to answer any question or curiosity from the students.

Figure 4. Diagram of skill improvement of reading and writing short story material through project-based learning

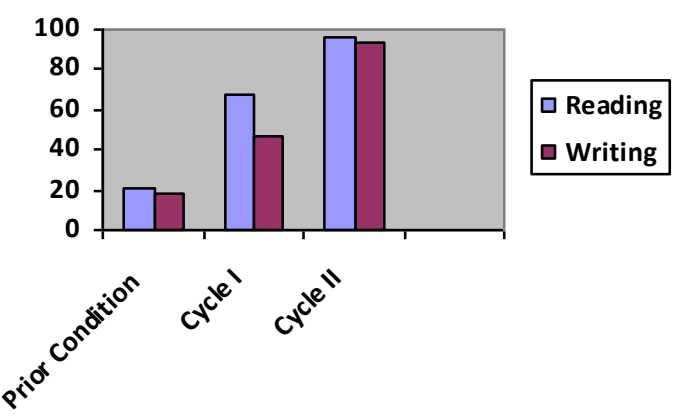

IV. CONCLUSION

Project-based learning in the learning process of reading and writing short story material is proven to be able to improve students activeness in learning of reading and writing short story material. Besides, the level of cooperation among students experiences improvement. The other improvement also occurs in the growth of self confidence of the students, such as during presentation and aswering question.

The application of project-based learning model in the learning of reading and writing short story of class IXF of Junior High School Negeri 1 Ngluwar can give impact on student behavior and attitude to the positive side such as active behavior, ability to cooperate, and self-confidence.

\section{RECOMMENDATION}

Teachers should use project-based learning to support reading and writing learning activities since this model can maximize students' activeness and creativity with proper Indonesian language structure. In addition, students can improve their comprehension of the short story and their general literacy. Consequently, the students are more excited to study to get better and better understanding. However, the teachers need to keep developing more appropriate learning materials in the forms of learning project to suit students' needs and capability.

For the students, project-based learning model can stimulate them to understand, read, and write short story more precisely. More students can be involved in the learning process since the model demands the students to interact with each other. Hence, the self-confidence of the students grow along with the process of communication and interaction with other students. 


\section{REFERENCES}

Abrams, M.H. (1970). A glossary of literary term. New York: Rinehart. Burns, R., \& Ross. (1984). Teaching reading in today's elementary s chools. Boston: Houghton Mifflin Company.

Endang, S. (2017). Penerapan model project-based learning dalam mentransformasi cerpen ke dalam film berorientasi pendidikan karakter siswa kelas XI SMA Negeri 1 Cipatat Kabupaten Bandung Barat. Tesis, Universitas Negeri Pasundan. Bandung

Hayes, J. (2002). The theory and practice of change management. UK : Palgrave Macmillan

Hedge, T. (2005). Writing. New York: Oxford University Press.

Hunchinson, T. \& Waters, A. (1987). English for Spesific Purpose: A Learning-Centered Approach. UK: Cambridge University Press

Kemmis, S. \& McTaggart, R. (1990). The action research planner. Victoria: Deakin University Press.
Madya, S. (2011). Penelitian tindakan acion reseach. Bandung: Alfabeta. Mahsun. Indonesian Knowledge Forum for SMP / MTS class VII. Jakarta : Kementrian Pendidikan dan Kebudayaan.

Rauf, S. (2016). Penerapan model pembelajaran berbasis proyek dalam meningkatkan kemampuan menulis cerpen pada peserta didik kelas XI MIA 4 SMA Negeri 2 Takalar. Tesis. Universitas Negeri Makasar, Makasar Saka, Ö. (2014). Short stories in English language teaching. International Online Journal of Education and Teaching (IOJET), 1 (4), 278288.http://iojet.org/index.php/IOJET/article/view/59/77

Smith, F. (1994). Understanding reading. (5th ed.). Hillsdale, NJ: Lawrence Erlbaum.

Tompkins, G. E. \& Hoskisson, K. (1995). Language art: content and teaching strategies. USA: California

Trianto. (2007). Model pembelajaran terpadu (integrate curiculum model) dalam teori dan praktik. Jakarta: Prestasi Pustaka 